\title{
REVIEW ESSAY
}

\section{What Do We Have in Common? A Comparative Framework for Old and New Literature on the Commons*}

\author{
Tine De Moor \\ Research Institute for History and Culture, Utrecht University \\ E-mail: t.demoor@uu.nl
}

Kos, Anton. Van meenten tot marken. Een onderzoek naar de oorsprong en ontwikkeling van de Gooise marken en de gebruiksrechten op de gemene gronden van de Gooise markegenoten (I 280-I 568). [Middeleeuwse studies en bronnen, vol. I25.] Verloren, Hilversum 2010. 445 pp. Ill. $€ 33.00$.

Rodgers, Christopher P. Eleanor A. Straughton, and Angus J.L. WinChester [a.o.]. Contested Common Land. Environmental Governance Past and Present. Earthscan, London [etc.] 20I I. xii, 227 pp. Ill. Maps. $£ 60.00$.

Poteete, Amy R. Marco A. Janssen, and Elinor Ostrom. Working Together. Collective Action, the Commons, and Multiple Methods in Practice. Princeton University Press, Princeton, [etc.] 2010. xxiii, 346 pp. \$85.00.; £59.00. (Paper: \$30.95; £21.95.)

\section{REINVENTING THE COMMONS?}

In a world where markets and the state have started to reach the limit of their capacities to govern resources in a sustainable way, society is turning increasingly to "joint resource management"; more and more, collective

\footnotetext{
* The research for this article was made possible by funding from the European Research Council under the European Community's Seventh Framework Programme (FP7/2007-2013/ ERC agreement no. 240928) as part of the project “'United We Stand': The Dynamics and Consequences of Institutions for Collective Action in Pre-Industrial Europe" (20I0-20I4). For more information on this project, see also http://www.collective-action.info.
} 
initiatives of "stakeholders", trying to reach their economic and social goals via collective action, are popping up in the developed world. Examples of such initiatives are energy consumers' collectives, car-sharing, and the development of open-source software. Although they may seem rather marginal as yet, these forms of institutionalized collective action are nevertheless gaining momentum. Many of the initiatives use the concept of "the commons" to emphasize that they are indeed sharing a resource. The "Creative Commons initiative" is nowadays the most well-known example of this trend. Yet, few participants actually know the real historical background of the commons.

There are two ways to explain what "commons" really were in the past: one could examine their similarities with present-day commons, from different disciplinary perspectives, or one could compare them with other institutions which have very similar characteristics, existing in the past or the present. The latter method, which I do not pursue in this review article, does show that commons were not the only kind of institution formed by a limited group of people "from below", and based on selfgovernance and self-sanctioning. In the pre-modern urban context, the guilds - among other organizations - also operated according to these principles, and dating from the nineteenth century, the cooperatives model had the same kind of characteristics. It is clear, though, that from the nineteenth century onward the importance of such institutions for resource governance dwindled compared to the growing role of markets and the state. As I have suggested, we now seem to have reached a "point zero", where we need to "reinvent" society. ${ }^{\mathrm{I}}$ Knowing what commons are, and what they used to mean for our society, could be a major source of inspiration for this task.

Like many popular topics in science, this subject needed a strong personality to put the spotlight on an already lengthy tradition of scholars, so that they would get noticed by a wider audience. When Elinor Ostrom received her well-deserved Nobel Prize for Economics in 2009, the literature on commons - or, in a more generalized form, common-pool resources - was already quite extensive, but only a minor part of it consisted of historical literature. ${ }^{2}$ Many British enclosure historians probably assume that their area of interest has been studied extensively, maybe even exhaustively. They might be surprised to learn that across the world, commons in diverse resources in all their forms and varieties are the subject of a large body of literature, which includes many different non-historical branches of science - from sociology to ecology and information sciences.

I. See also my brief article "De herontdekking van het collectief", at http://www. socialevraagstukken.nl/site/201 2/03/2 I/de-herontdekking-van-het-collectief/.

2. See Frank Van Laerhoven and Elinor Ostrom, "Traditions and Trends in the Study of the Commons", International Journal of the Commons, I (2007), pp. 3-28. 
For anyone taking an interdisciplinary approach to the specialism they study and know well, it can be a challenge to know what is "already out there" - what has been thought by scientists from other disciplines and taught to scholars from different backgrounds. In this article, I attempt to provide some "structure" for the existing interdisciplinary literature on the commons. I will do so not by analysing schools or the followers of acknowledged authors - though some "leaders" in the field will be identified - but by bringing together the topics addressed in this literature and the approaches being proposed.

A thorough analysis of the commons literature shows us that a particular opinion on a specific theme in the commons literature is often at least implicitly combined with opinions on other issues at the forefront of different sub-debates about commons. Thus, scholars who believe in the capacity of commoners to manage their resources sustainably, will also have particular views on the importance of common-pool resource management for agriculture, or for the socio-economic wellbeing of the commoners involved. And there are links even to their opinions on the origins of commons. The analysis I provide might help social historians (but also other scholars) to grasp the big themes in the commons debate more rapidly and more thoroughly.

This is important, because current debates on commons, as I have already indicated, start from a clear positive view on the potential of commons as a governance regime - one that has other, and possibly more advantages compared to what the state or the market can offer. As I will show, a positive perception of the potential of commons to manage resources often also goes together with a positive view on, for example, equality in the distribution of those resources among commoners. This last point is exactly an issue that is insufficiently studied among social historians, but which deserves extra attention - especially given the new application of commons as a concept for today's resource governance. It will become apparent from the three books discussed in this article that the recent literature still pays only limited attention to the social dimension of the commons. Using an interpretive framework I develop further on, these three new works will be put in a broader perspective.

The historical study by Anton Kos deals with a very lengthy period of historical development of commons in the northern part of the province of Holland. The more interdisciplinary study by Rodgers et al. deals with common land in England and Wales from a present-day perspective, but with much attention paid to the historical background of all the casestudies the authors describe. The very interesting work of Poteete, Janssen, and Ostrom makes the life of both the beginning and the experienced commons-researcher much easier, by bringing the methodological implications of this vast body of literature on commons together, including also some references to historical work. 
In the second part of my review, I discuss how interdisciplinary research translates into a multitude of possible methodologies applicable to the commons. The large spectrum of opinions and ideas which has developed over the past thirty years has involved many different methodologies, from field work to laboratory experiments. Most studies on the commons whatever method they have applied - have focused on contemporary commons. There is, however, a growing interest in studying institutions across much longer periods of time. This trend has implications for the methodology used, because not every method used for contemporary research can simply be applied to historical research as well. But it also offers many opportunities for historians. New theoretical frameworks can help us to overcome the purely "descriptive" level at which much of the history of the commons can still be found. And historians can contribute to the approaches taken by other disciplines: only with a long-term perspective can the resilience of institutions for collective action really be understood.

\section{STRUCTURING THE COMMONS DEBATE: TERMINOLOGY, RESEARCH QUESTIONS, AND APPROACHES ACROSS TWO CENTURIES}

Commons researchers from various historical and non-historical disciplines differ in the research questions they pose, in the terminology they use, and - as will be shown in the second part of this article - also in the methodologies they apply. This makes interdisciplinary research really difficult, but also rewarding, work. A first step should be taken toward bringing the scientific parties together, not by pointing to their differences, but rather by identifying the structure in their similarities. Before we can place commons research in the summary figure below (Figure I), however, the terminological chaos that has developed over the past decennia should be cleared up a bit.

Commons (or "goods used and managed in common") are found in past as well as in the present. The original "historical" use of the notion "commons" was, however, limited to the "territorial" type: it meant land used in common to produce hay, wood, or peat, to provide pasture for the cattle of the local population, and to supply other natural resources for construction and housekeeping. The great variation in the physical characteristics of the commons has caused a great diversity in terminology, which hinders comparative research. The terminology used has also blurred variations in the forms of property of the commons, and in the degree of autonomy applied (which can have far-reaching influence on the management of a common).

Historically, commons were managed by the users themselves, or their elected representatives, or by the local authority. The way in which commons were managed could range from a co-operative-like 


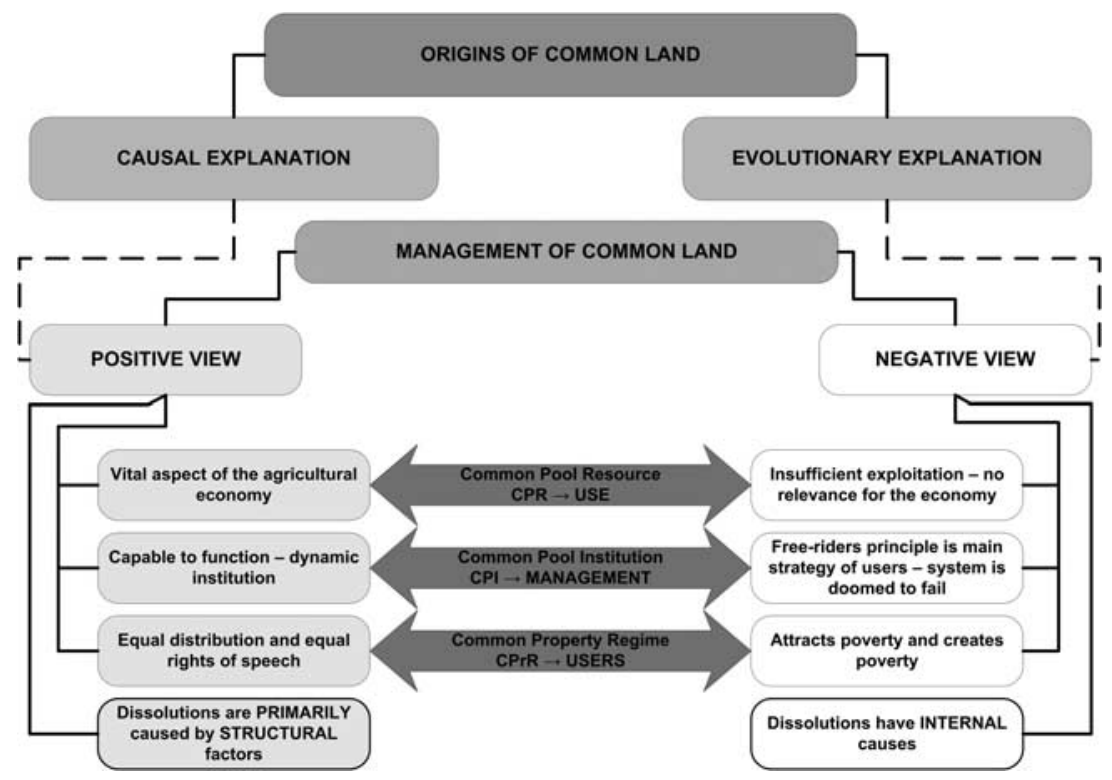

Figure I. Overview of different opinions on commons, structured horizontally by the different dimensions (CPR, CPI and CPrR), and vertically by the associated positive or negative connotation in the literature.

system (for example, the German Genossenschaften ${ }^{3}$ or the Dutch markegenootschappen ${ }^{4}$ ) to a management that was mainly recruited from local notables, but with access for most members of the village (in Dutch the so-called meenten ${ }^{5}$ ). On top of that, the same term can mean different things. For example, an "open field" can refer to the physical openness of a field, and to the common character of the use of the good. ${ }^{6}$ Outside the historical context, the term "commons" is being increasingly used, too, not just for the tangible physical forms of institutions at least similar the historical commons, but also for less tangible (or even virtual) forms of goods being shared among large groups of people. ${ }^{7}$ The term "commons"

3. Stefan Brakensiek, "The Management of Common Land in North Western Germany", pp. 225-245 and Paul Warde, "Common Rights and Common Lands in South West Germany, I 500-I 800", pp. 195-224; both in Martina De Moor, Leigh Shaw-Taylor, and Paul Warde (eds), The Management of Common Land in North West Europe, c.I500-I850 (Turnhout, 2002).

4. Peter Hoppenbrouwers, "The Use and Management of Commons in The Netherlands; An Overview”, in ibid., pp. 87-1 I 2.

5. Ibid.

6. Martina De Moor, Leigh Shaw-Taylor, and Paul Warde, "Comparing the Historical Commons of North Western Europe", in ibid., pp. I 5-32, i 8.

7. See Charlotte Hess and Elinor Ostrom, Understanding Knowledge as a Commons: From Theory to Practice (Cambridge, MA, 2007), but see also initiatives such as http://creativecommons.org/. 
has also been "stretched" substantially, by applying it to resources which remain open-access goods, such as the oceans or clean air, despite a growing tendency to restrict access to them by establishing private property rights (e.g. the tradable "emission rights" which are part of the Kyoto Protocol). ${ }^{8}$ Among historians, the concept of commons remains mostly limited to land. ${ }^{9}$

To avoid controversy caused by this rather liberal use of the term "commons", I focus in this article on literature that deals with commons in natural resources, with the emphasis on pastures. Even within this segment of the literature on commons (both historical and contemporary research), a plethora of opinions and ideas abound.

There is another factor complicating what the term commons really stands for, even within restricted context I have just described. Namely, it can refer to not only the natural resource itself, but also to the property regime limited to it, or even to the group of people that is entitled to use the resource. The first-mentioned meaning (natural resources) corresponds with what generally falls under the heading of "common-pool resources" (CPR). Elinor Ostrom describes "common-pool resources" as "natural or man-made resources sufficiently large that it is costly to exclude users from obtaining substractable-resource units". ${ }^{10}$ On the basis of this definition and further literature, one assumes that it takes two criteria to define a CPR.

Firstly, there are the high costs of the physical exclusion of the natural resource ("excludability"). ${ }^{I I}$ The larger a territory, the more difficult it becomes to exclude others from using it. Such a territory has a lower excludability than a small, controllable territory. The expenses of exclusion are fixed on the one hand by the size and type of the natural limits of the resource system, and on the other hand by the available technology to enclose the good (hedges, fences, etc.).

Secondly, there is the issue of the presence of "substractable resource units"(or "substractability"). Substractability is in the first place related to

8. The problems this multiple use of the term "commons" brings along have been discussed at length in Tine De Moor, "From Common Pastures to Global Commons: A Historical Perspective on Interdisciplinary Approaches to Commons", Natures Sciences Sociétés, I9 (20I I), pp. 422-43I.

9. In a few exceptional cases, historians have applied theoretical frameworks developed to understand commons, such as the framework of Elinor Ostrom, Governing The Commons: The Evolution of Institutions for Collective Action (Cambridge, I990), to other common-property systems than land, such as water boards; see e.g., Brigitta Dolfing, Waterbeheer geregeld? Een historisch-bestuurskundige analyse van de institutionele ontwikkeling van de hoogheemraadschappen van Delfland en Rijnland I600-I800 (Leiden, 2000).

Io. Ostrom, Governing the Commons, p. 30.

I I. Idem, "The Rudiments of a Theory of the Origins, Survival, and Performance of Common Property Institutions" in Daniel W. Bromley, David Feeny et al. (eds), Making the Commons Work: Theory, Practice and Policy (San Francisco, CA, I992), pp. 293-318. 
the limitations imposed on users of a resource by nature and technology. ${ }^{\mathrm{I2}}$ Describing the excludability and substractability of a good helps to anticipate difficulties that may arise in the case of common use, and explains the necessity for regulation, organization, and institutionalization of that use. After all, each natural resource is limited; it can only support a limited number of users at the same time without having them collide with each other, or decreasing the yield available for the group of users as a whole. The extent to which the resource has this capacity (or the extent to which more than one commoner can use the same resource without causing the level of the resource to decrease) is expressed with the term "substractability". ${ }^{3}$ Historically, commons could vary substantially in size and boundary definitions; this remains true even today. They could range from the large markegenootschappen in the eastern part of the Netherlands (with their rather vague physical boundaries) to small commonly used meadows in some parts of Flanders. Whatever the case, exclusion from the common was achieved primarily via formal access rules. In some cases, the physical delimitation of the commons was obtained by the description of a zone wherein one had to live in order to be qualified as a commoner. ${ }^{14}$

The property regime of a common is a second dimension. The term common-property regime $(\mathrm{CPrR})$ refers to a property regime "somewhere" in between private property and public property. Drawing a precise boundary between private property and public property on the one hand, and common property on the other, is very difficult - especially for pre-1 800 Europe, but also for the present day. The reason is that goods subject to common-property rights in several respects show a strong resemblance to both private goods and public goods. Common goods and private goods resemble each other with regard to the substractability of the goods in question: every "unit" of the resource which is consumed can no longer be consumed by someone else. Public goods (for instance, street lights), can in most cases be consumed multiple times by several persons.

The difference with private property is that commons cannot be divided among their users, either because it is physically impossible, or because the costs of subdividing the good are so high that they cannot be compensated by the income obtained from doing so. This means that CPRs are "low in divisibility", a characteristic they have in common with pure public goods, which contrasts with the high divisibility of private property. Commons should however be distinguished from "open access

I 2. Ronald J. Oakerson, "Analyzing the Commons: A Framework”, in ibid., pp. 4I-62.

I3. Bromley and Feeny, Making the Commons Work.

I4. See, for example, the case of the Beverhoutsveld in Flanders in Martina De Moor,

"Common Land and Common Rights in Flanders", in De Moor et al., The Management of

Common Land, pp. I I $3-142$. 
goods", also called res nullius ("nobody's property"), which refers to a territory for which no property rights have been recognized. ${ }^{15}$ In the case of open access, there are no rules regulating individual use rights. Thus, open access problems arise from unrestricted entry, while commonproperty problems stem primarily from tensions caused by the fact that individuals have to cooperate.

In long-term studies (more than 200 years, going back to the ancien régime), the term "property" causes problems: it is hardly applicable in the situation of the ancien régime, where the feudal structures of society resulted mostly in a rather complex collection of different claims by different individuals and groups on the multitude of resources which one piece of land could produce. A "common-property regime" should - at least when discussing pre-nineteenth century developments - be defined as a bundle of rights on land (or other resources) rather than the more absolute interpretation of property that is used today.

Compared to the present-day organization of property rights, the ancien régime system was more flexible: on the basis of a local agreement between the involved parties (lords, commoners, representatives of the local administration, etc.) the rights to common resources could be rearranged. Their management could be adjusted to changes in the environment, or the needs of any one party. It should not be assumed that commoners always had to make concessions; depending on the circumstances - which, before the eighteenth century, were often advantageous for the commoners - they could claim new rights or adjustments of the regulations to their advantage. ${ }^{16}$ Also, because of the explicit management prescriptions which accompanied use rights, and the possibility of ad hoc changes, the rather easily adjustable system of property rights of the ancien régime offered in most cases more opportunities for a sustainable and equitable management of the commons than the new juridical system introduced in most western European countries from the late eighteenth and the early nineteenth century onward. ${ }^{17}$ Aside from the changed

I s. C. Ford Runge, "Common Property and Collective Action in Economic Development", in Bromley and Feeny, Making the Commons Work, pp.17-27, I8. See also S. von CiriacyWantrup and Richard C. Bishop, “Common Property' as a Concept in Natural Resource Policy”, Natural Resources Journal, is (1975), pp. 71 3-727.

I6. See e.g. De Moor, "Common Land and Common Rights in Flanders".

17. The introduction of the "Code Civil" (or Code Napoléon, I804) in several western European countries allowed, for example, only a temporary form of legal recognition to a group of persons who had land in common but - as a group - did not form a legally recognized administrative unit (i.e. a municipality). Whereas property that was common to all inhabitants of a municipality (and thus was the property of that municipality) could be kept in common (art. 524 in the Belgian Code Civil). In comparison to the ancien régime, the legal security of the "closed type" of common property (see further) was seriously reduced, and the autonomy in managing their common natural resources - without the interference of local administrative bodies - was affected. In these 
juridical circumstances, it should not be forgotten that changes in agriculture and society also contributed to a weakening of the commonproperty systems by the mid-nineteenth century.

The interaction between the first dimension - commons as natural resources - and the second dimension - the users of the commons - required a certain form of organization. The institution set up to make that organization possible - the common-pool institution (CPI) - can be considered as the third dimension of common land. Almost everywhere in north-western Europe, reasonably sophisticated institutions were set up to manage common land. For the most part, they involved users as the jurors in manorial or village courts, and as monitors of the day-to-day use of the common. As such, they usually also had the power to alter management rules. These institutions often, though not always, appear to have had a system of graduated fines for punishing wrongdoers. They drew up by-laws approved or amended by the lord, the lord's court, the village court, or the assemblies of users. Historical examples of such autonomously functioning institutions can be found, among others, in Germany (Genossenschaften) and the Netherlands (markegenootschappen). Next to these corporate organizations, common land could also be managed by the local political-administrative organization. An example is that of the Dutch "gemeenten", which were managed by the local village/municipality. ${ }^{18}$ The markegenootschappen are the type of common dealt with in the book of Anton Kos, which I discuss in more detail below.

In summary, the terms "common-pool resource", "common-property regime" and "common-pool institution" refer respectively to the use, the users, and the management of the commons. Apart from the advantage of terminological clarity, applying these three dimensions allows us to approach the functioning of common land in a coherent and systematic way. The diagram in Figure $\mathrm{I}$ is structured according to these distinctions. It provides a conceptual framework for interpreting the commons literature.

\section{FRAMING THE COMMONS LITERATURE (INCLUDING REVIEWS OF KOS AND RODGERS ET AL.)}

As regards the content of the debates, historians have placed the emphasis almost exclusively on the dissolution of common land. Since the middle of the nineteenth century, common land vanished almost completely from the western European landscape and from the collective memory of the Europeans. This process was accelerated by the questioning of common

circumstances, national privatization laws - in Belgium in particular the Privatization Law of 1847 - had comparatively a much greater success in dissolving the commons than the legislation of the eighteenth-century Austrian and French regimes.

I 8. For equivalent institutions elsewhere in north-western Europe, see the chapters in De Moor et al., The Management of Common Land. 
customs and common management of goods since the mid-eighteenth century, in particular by the politically influential physiocrats. ${ }^{19}$ Historians researching Great Britain - and England in particular - have focused primarily on the social consequences of the enclosure movement, i.e. the possible negative effects (such as "proletarianization") on the commoners. ${ }^{20}$ Social scientists began to investigate commons in particular from the I970s onward, after the publication in 1968 of the influential article on "The Tragedy of the Commons" by Garrett Hardin in the journal, Science. ${ }^{21}$ Since the founding of the Common Property Resource Network in 1984, and the resulting International Association for the Study of the Commons in $1989,{ }^{22}$ quite a few studies have pointed out the capacities of common management regimes for natural resources.

What, now, is the connection between the diversity of views and assumptions which have been adopted within the different disciplines in the course of time? And, how can we structure the different approaches, in order to stimulate a dialogue between social scientists and historians? I use two methods to structure the debate, as illustrated in Figure I: the opinion (negative or positive) of the researcher about the capacities of common-use systems, and the three different dimensions previously defined. We can assume that all views on different aspects of the commons come down to identifying a negative or positive causal relationship between the governance regime and the state of the resource. The negative view assumes that the governance regime led to a deterioration of the state of the resources. The positive view assumes that the property regime is a necessary consequence of the resource: the governance regime is adjusted to the particular type, amount, and value of the available resources, and not the other way round. In this view, a common-property regime can be useful and effective. The positive view also leaves space for other governance regimes, and does not consider the management and use in common as infallible. The negative view claims the opposite: the collective use and management of the resources is precisely the cause of (or leads to) an inferior good, and in the end can even result in a tragedy.

19. In the southern Netherlands, the Hapsburg emperors Maria Theresa and Joseph II especially were influenced by physiocratic ideas. See, among others, J. Dupont, "La politique agricole en Hainaut sous Marie-Thérèse", in Université Catholique de Louvain (ed.), Miscellanea historica in honorem Leonis van der Essen, Universitatis catholicae inoppido Lovaniensi iam annos $X X X V$ professoris (Brussels [etc.], I947), II, pp. 855-869; H. van Houtte, Histoire économique de la Belgique à la fin d'Ancien Régime (Ghent, I920); E. Clicheroux, "L'évolution des terrains incultes en Belgique", Bulletin de l'Institut de recherches économiques et sociales, 23 (1957), pp. 497-524. 20. J.L. Hammond and Barbara Hammond, The Village Labourer I760-1832: A Study in the Government of England before the Reform Bill (London [etc.], I9I I).

21. Garrett Hardin, "The Tragedy of the Commons", Science, I62 (New Series) (1968), pp. I $243-\mathrm{I} 248$.

22. See www.iasc.info. 
The second method I use to structure the debate is that of the use of the three dimensions of the commons discussed earlier, namely the management of the institution, the users, and the use. However, I will start out - as behoves a good historian - with the origins of the commons; it is already there that the dichotomy between the two sides in the debate can be found. As regards the origins of commons, we can distinguish two "traditions" of explanation: the evolutionary explanation and the causal explanation. In the first type of explanation, there is only one possible direction common property can move toward, namely private property. The associated conviction is that common property stems from ancient forms of "Germanic" tribal communism, and evolves via clan holdings to individual property in severalty. When exactly the transition of collective to individual property happened, remains unclear however.

Scholars supporting this view suppose that common land was an "archaic" and "inadequate" system for the management of natural resources. One proponent of this view was Emile De Laveleye, who, in his substantive work De la propriété collective et de ses formes primitives (I89I), ${ }^{23}$ made an international comparison of collective property, and discerned a similar evolution in different parts of the world: common "primitive" systems always had to - and always would have to - make way for private property. This view is typical for the late nineteenth century. ${ }^{24}$ Although such a position on the origins of common land is considered outmoded these days, it does persist implicitly in the literature and debates over various aspects of common land, as is illustrated in Figure I.

A specific property regime can also be the result of a choice between several alternatives. Thus, the causal explanation shows analytical similarities to the so-called "commons dilemma". Different factors can have played a causal role. In the economic variant of the causal explanation, the value of a good determines the property regime chosen for the management of the goods. "Value" must, however, be interpreted as a relative notion here. The reference value (the resource compared to the common good, in order to determine its value) is determined by the market value of the good. A good is of "low value" because the produced goods - also in large quantities - have only a limited market value, or because the resource produces only few valuable goods. As long as one does not invest in the good to enhance the value of the resources it produces, the value of the common as a whole remains - from a relative perspective - low. Because of the lack of investment in the good and the possible mismanagement this can entail, the value can diminish further. In other words: the value of a good can

23. Émile de Laveleye, De la propriété et ses formes primitives (Paris, I891).

24. Ibid. 
change under the influence of the qualities of the management, and this might necessitate a change of property regime.

Aside from the actual market value of a good, the value of a good - and common goods in particular - can also be influenced by the importance of the resources in the local economic (mostly agricultural) system. The extent to which an agricultural system is dependent on, for example, the manure that is produced by cattle on the common, can influence the value of the common. If, in the case of a deficiency, it is possible to replace this good (for example by artificial fertilizers), this influences the value of the good for the local population. If the scarcity is related to a lack of a crucial part of a particular (agricultural) production system ("qualitative scarcity"), it becomes more important to create a good balance between all parts of the system, than creating more resource units of the scarce resource. In other words: the context in which a good functions is as important as its market value, in order to decide upon the desirability of a common-property regime.

Secondly, when the value of a good is limited, it is economically speaking not interesting for individuals to invest in. A common-property regime offers a number of scale advantages in management and transaction costs. The managerial expenses (among others, fences and hedges to protect the common for improper use by others than those entitled) can be lowered as the surface of the territory increases. In that case, it is more advantageous to meet these expenses as a group, rather than as an individual - and to divide especially the expenses of drainage and fencing among a large number of individuals.

Thirdly, the spatial variability of land yields can, in a traditional agricultural system with few external inputs (artificial fertilizer, irrigation and drainage, etc.) be an important incentive to choose for common property. Runge describes this argument as "natural resource dependency". ${ }^{25}$ Because the distribution of natural resources (such as land or water) is arbitrary in time and space, the granting of exclusive rights over a specific area can mean an unfair distribution of resources. In comparison, common access can provide fairer results.

Fourthly, private rights and the inequality they bring with them can, in the end, have destabilizing effects. Poverty and an arbitrary distribution of wealth can result in a high degree of income insecurity. In a developed economy, the vagaries of nature are much more under control. Common management (in a CPI) and possession (in a CPR) can form a bulwark against uncertainties created by the forces of nature. Common use and management must - in this sense - be considered as a form of risk-sharing, or a type of insurance against bad harvests. 
Fifthly, the expenses of the transition of common to private property, the so-called transformation costs, can play a role. Norberg argues that next to the limited yields of the French commons, the large expenses required to privatize the good played an important role in the conservation of the commons. ${ }^{26}$ The social overheads required (to attribute private property rights, to define them legally, to make these rights transferable, and to make this structure function) are often invisible, but they can be substantial nevertheless. Imposing private law can be considerably more expensive then customary agreements. Those claiming that CPIs cause poverty have, according to Ford Runge, mistaken the cause for the consequence: the CPI did cause poverty, but the poverty of the users caused them opt for a more advantageous property regime. ${ }^{27}$

On the basis of this dichotomy between evolutionary explanations and causal explanations, all the other hypotheses raised in the debates can be ordered. My schema of the debates (Figure I) indicates that researchers who are convinced that the commons can be managed efficiently, are mostly also convinced of the economic importance of the commons in general, and of the utility of the common for the user. They emphasize that the common management system was not necessarily responsible for the poverty of its users. By contrast, those researchers convinced of the inadequacy of a common-property system for the management of natural resources mostly emphasize that the local economy was not, or is not, dependent on the resources obtained from a common, that these were unimportant for the commoners, and that these resources even led them into a state of destitution.

Figure I is useful to evaluate the historical works under review, because it incorporates and connects opinions about commons in terms of both their origins and their functioning, and it relates these aspects to each other. Within this framework, I begin with Anton Kos. Kos's work is a rather traditional case study of a very large Dutch common, het Gooi, consisting of about 7,500 hectares of heath lands, waste lands, fens, etc. It was the last surviving common of its type in the Netherlands. Kos's main concern, however, is not with the final period of the Gooi-culminating in its dissolution in 1979 - but rather with the first period, from I 280 to I 568 . His main concern is clearly with the origins of this common, which makes it an interesting case to test the model shown in Figure $\mathrm{I}$.

Although Kos leaves some room for interpretation, undoubtedly he supports a more causal explanation of the emergence of the markegenootschappen. He stresses the importance of reclamation, and traces the roots of the conflicts between the various parties which were present at

26. Kathryn Norberg, "Dividing up the Commons: Institutional Change in Rural France, 1789-1799", Politics and Society, I6 (1988), pp. 265-286, 273.

27. Ford Runge, "Common Property and Collective Action", pp. $70-72$. 
the beginnings of institutionalized collective land use in the area. Kos's explanation of the conflicts between farmers and lordly powers (in this case the Dukes of Holland), and of the role of urbanization and the nearby city of Naarden in the politics of expansion is impressive (see especially chapter I). Yet Kos remains quite ambivalent in his approach to the emergence of het Gooi. A very large part of his book is taken up by an analysis of the internal organization of the county of Holland, in order to bolster his assumption that there must be some truth in the Hofmarke theory as well (which would suggest that the emergence of the Gooi commons was more of an evolutionary, than a causal type). However, on almost every page of the book there is mention of conflicts, negotiations, and discussions, prompted especially by the land reclamations, and culminating in a series of legal documents (the so-called schaarbrieven and bosbrieven, of which the first dates from 1364) by which land use and management was very strictly regulated.

For a commons researcher, it is surprising and somewhat frustrating that Kos did not take one step further to understand why this common, which survived several government-orchestrated attempts to dissolve it, successfully resisted and survived until the end of the i970s. So while he provides a very robust "skeleton" for the analysis of institutional changes, his approach is not without problems. Kos does briefly discuss the tragedy-of-the-commons debate at the beginning of chapter 3 (five pages in total) and mentions the standard literature on the subject. Yet he fails to understand the link between the institutional resilience and the internal organization of this common via - amongst other means - the schaarbrieven and the sanctioning system that went with it. Although his description of the regulations is very detailed, Kos does not recognize different gradations in them (such as the graduated sanctioning system). He fails to identify the incentive structure, and does not explain how important (or unimportant) the common actually was for the livelihood economies of the commoners. Kos highlights the conflicts between many different parties, and explains these conflicts in the great detail, but he fails to explain how it was possible that such conflicts were overcome time and time again.

His description of the regulations in fact shows a very well-organized institution, which was directed towards avoiding excessive harvesting. $\mathrm{He}$ does acknowledge this in the conclusion of chapter 3 ("in fact the schaarbrieven functioned in a most optimal way"). ${ }^{28}$ Yet instead of supporting this most interesting conclusion with comparative material from other markegenootschappen with similar regulations, he turns to conflict once again. Considering the longevity of this case - and many other cases - it might have been useful to pay attention to what happened between conflicts 
as well, and how it was possible to manage the common successfully for such a long time, despite all the internal and external conflicts.

Chapter 4, entitled "Who is the Boss?", describes in detail how the use and property rights over the common developed, via many different conflicts which are discussed. Here again, Kos misses an opportunity to link his findings to the debate on the governance structure of the commons, and to the question of how "bundles of rights" should be managed. The chapter is strictly limited to a description, without any room for debate or abstraction. The commons researcher has the same frustration in chapter 5, where the boundaries of the Gooi common are discussed. All in all, this discussion ought to have been placed much earlier in the book, and one wonders whether it would not have been more appropriate to combine it with the discussion on the emergence of the Gooi common (chapter I). Kos describes all the boundaries of the vast common in detail, how they came about, and how they changed over time, but again he misses the most important point. It is clear from his very well-documented description that the boundaries of the common were not only well known, but also very well internalized - both by the entitled users, and by those who wanted to use the land although they were not allowed to do so. This is an important finding, as Elinor Ostrom also points out in her list of design principles (in which "well-defined boundaries" are ranked first). ${ }^{29}$ In fact, it proves once again that the idea of commons being "open to all" - a frequent assumption in the tragedy-of-the-commons-debate - is historically false and ridiculous.

Kos's last chapter is devoted to the evolution of the Gooi common in its final period, until its dissolution in I979. It deals mainly with the conditions which led to the promulgation of a specific law, the so-called Erfgooierswet. This law was enacted especially for this specific common, in order to give it the legal backing which it had lacked since the end of the ancien régime. In this whole story, which spans several centuries, the role of the small cotters (keuters, or peasant farmers) stands out as a driving factor for the changes, but again little is said about the extent to which the common still had real economic value for the commoners. Throughout the whole book, the social background of commoners is hardly an issue. It is therefore impossible to evaluate whether the social heterogeneity of the commoners - and changes in their social status - would have influenced the history of the common as such. It is remarkable that Kos does not make any effort to put important developments - for example, the decision to use part of the common in the battle against poverty, or the top-down interventions and attempts to privatize the common - in a more international perspective. Both of these developments represent evolutions 
which can be found in any western European country in this time in history, and are in this sense part of the liberal Zeitgeist. ${ }^{3 \circ}$

All in all, Anton Kos's book is very valuable for the specific and detailed information it provides about its case study, across a long period of time. His book title suggests a study which does not go beyond the sixteenth century, but in fact he proceeds all the way to the dissolution of the common. Yet exactly this longitudinal approach demands that an author should try to identify trends and broad, long-term evolutions. The type of the information Kos gathered, for example about the regulation of commons, ought to have been placed in a comparative perspective. The conclusions drawn from his long-term study would have been better placed in a wider, comparative perspective. In fact, no other common is discussed throughout the book, which is regrettable.

The work by Rodger et al. is of an entirely different nature. It is the result of an interdisciplinary research project carried out in 2007-20I0. Contrary to "joint-work publications" that such projects often deliver, with articles co-written by various authors, this book is a genuinely "common" publication, starting from a shared interdisciplinary perspective. Whereas Kos's book takes a more traditional approach (tracing the history of a common from beginning to end), Rodgers et al. start out from what is still left of the commons today. In the second part of the book, they select a number of examples in England and Wales as case studies, to exemplify the broad framework on "custom, property rights and sustainable management" they developed in part I. The final part of the book discusses a number of reflections on common-land governance, and - what is most remarkable, for an historical study - draws some lessons from common-pool scholarship.

The introductory first part provides a very clear overview of the situation of common land in England and Wales, past and present, and the theoretical framework used to understand the institutional diversity which the various types of commons in England and Wales represent. But most importantly, the authors take the time to explain the legal background of the commons in the country, all the way from medieval times to the present-day developments (with the new 2006 Commons Act). Their study focuses on three main issues: sustaining the common resource for present and future generations; protecting environmentally sensitive ecological and landscape features; and ensuring fair and equitable access to the land resource. ${ }^{3 \mathrm{I}} \mathrm{By}$ identifying these three issues, they also disclose straightaway their own position within the framework presented in Figure I.

30. See e.g. Marie-Daniëlle Démelas and Nadine Vivier (eds), Les propriétés collectives face aux attaques libérales (1750-1914). Europe occidentale et Amérique latine (Rennes, 2003).

31. Rodgers et al., Contested Common Land, p. I4. 
Rodgers et al. are "believers" in the commons. It follows that they do not question the viability and potential of the common as a governance regime, but want to find out which legal and organizational conditions work best to achieve sustainable resource management. An interesting and, I think, laudable feature is that they include "equitable access" in their list of objectives. It shows that they are not only convinced of the potential of the sustainable resource management, but also that they believe it can be done on an equitable basis, and that regulations can be modified to make that possible. Rodgers et al. do not intend to "re-invent the wheel" when defining the necessary conditions for achieving sustainable and equitable resource management; they rely upon a number of models (including Ostrom's list of design principles) to structure their research.

The second part comprises four geographically distinct case studies, situated respectively in Cumbria, North Yorkshire, Powys, and Norfolk, each with differing types of resource use, legal arrangements, and environmental problems. The case studies help us to understand how environmental governance on a national level affects commons on the local level. In this part, in particular, the added value of the interdisciplinary approach becomes apparent, since custom is still highly important in the governance of English commons. Although, on the continent, the introduction of a new legal regime at the beginning of the nineteenth century removed most of the customs on which they relied for their legal validity, the commons in England and Wales, where the destruction of common rights had started first - with enclosures occurring already in the fifteenth century - still rely on many customary rights today. Despite this difference between continental Europe and England and Wales, the commons had an equally difficult time with the legislative framework in both England and Wales (especially after the Commons Act of I965, which mostly suppressed legal recognition of local custom).

This issue is taken up in more general (but no less relevant) terms in their last chapter. Here, I believe, the authors point to a very important point for the functioning and viability of all institutions for collective action: the tension between law as a social construct and as custom. From the nineteenth century onward, centralization and homogenization of the law led to a situation whereby "once assimilated into a legally enforceable rule, custom will not necessarily cease to be reflexive - but it will be capable of modification and adaptation only in accordance with the rules appropriate to the particular normative legal order of which it now forms part”. ${ }^{32}$ This issue goes right to the heart of the resilience of customary collective institutions, and thus to the whole question of whether such collectivities can or cannot be durable institutions (see Figure I, the CPI-line). The authors' call for 'legal governance rules to reflect the flexible and iterative nature of customary 
practice" is one that probably deserves more attention than they actually realize. This plea is, in fact, also in conflict to a certain extent with their plea for more attention to the commons as "cultural heritage" and "traditional practice" ${ }^{33}$ Although there are good cultural reasons to preserve commons, this approach might however reinforce the idea that commons are not dynamic in nature, but static remnants from the past. Their way out of this conundrum is the "legal pluralist" approach, which is in itself not new within this field of study, ${ }^{34}$ but how exactly it would work in the present-day European context, still remains to be demonstrated.

One of the remarkable aspects of this book is that the authors not only manage to explain the long-term evolution of the complex legal structure governing commons, but also connect it to the ecological changes the commons have gone through, and to the changes in use of the common resources over the past three centuries. Parallel to this narrative, they sketch the changes in the perception of common rights, in relation to new functions - for example, the shift from agricultural to recreational uses in the late nineteenth century. The historical descriptions form a solid basis for the evaluation of the present-day management and future perspectives provided for each case study. At the same time, the authors try to trace how governance mechanisms used at the local level since the seventeenth century reflect changing concepts of sustainability. For an historian, it is a challenging endeavour to offer policy advice, but (I think) not one that we should try to avoid.

In the final part, the authors of Contested Common Land discuss which lessons can be drawn, given their theoretical framework and case study analysis. Altogether, this book is a very solid study on the commons in England and Wales, which ought to be an introductory text for commons scholars and practitioners in England, Wales, and the rest of Europe. The only "missed opportunity" in this book is the lack of a more systematic analysis of legal regulation, but that might be something for a Contested Common Land, volume II.

\section{LEARNING FROM INTERDISCIPLINARY \\ METHODOLOGICAL VARIATIONS IN COMMONS STUDIES (INCLUDING A REVIEW OF POTEETE ET AL.)}

The problems accompanying - but not necessarily caused by - the common use of resources have been the topic of social and scientific

33. Ibid., pp. 197-199.

34. See a.o. R.S. Meinzen-Dick and R. Pradhan, "Implications of Legal Pluralism for Natural Resource Management". IDS Bulletin 32:4 (200I), pp. 10-17, and idem, "Legal Pluralism and Dynamic Property Rights”, CAPRi Working Paper No. 22 (Washington DC, 2002); available at http://www.capri.cgiar.org/pdf/CAPRIWP22.pdf; last accessed March 2012. 
debates since antiquity. This fact is not surprising: until the middle of the nineteenth century, the common use of land (mainly for agriculture) and its common management was a normal practice in Europe. Common land was eliminated during the nineteenth-century "liberalization wave" sweeping through most western European countries. ${ }^{35}$ Until then, commons had provided an important contribution to the mixed agriculture system as a whole: the cattle on the common provided fertilization essential for the arable fields; and fuel (peat, cuttings of wood), building materials, heath, as well as other products found on the common were vital for everyday life. With increased external inputs (fertilization, seeds) and the increasing specialization and commercialization of agriculture, the necessity of the commons gradually disappeared.

Notwithstanding the assumed importance of commons in history, the number of historical studies on the subject is rather small, except for the United Kingdom - where the privatization (enclosures) of the commons is supposed to have had far-reaching social consequences for their users. In line with this, historians have in their studies mainly focused on two aspects: the disappearance of the commons, and the consequences of their disappearance for the commoners' social welfare. Commoners were mostly studied as groups, not as individuals with different strategies for the use of the commons. Social scientists other than historians have, however, concentrated primarily on the effect of individual behaviour on both the functioning of the common as a system of resource management, and the optimization of management and use of common-pool resources (a theme only recently discovered by historians). ${ }^{36}$

Apart from their rather limited interest in the topic of optimizing resource use, historians have also had little interest in the methods and results of other social sciences - even though these could help to raise historical research about the commons beyond its mainly descriptive level. I do not need to extol the advantages of interdisciplinary research here again, but historians ought to realize that they can not only benefit from "looking over the fence to what the neighbours are doing"; historical research is also very much needed for a better understanding of the longterm effects of resource use in our environment, both in the ecological, social, and economic sense. In recent years, non-historical social scientists have shown an increasing interest in the historical dynamics and historical contexts which shaped the development and change of the commons.

One of the big differences between a historian's approach to the commons and the approach of other kinds of social scientists is without

35. For an overview of the dissolution of commons in Europe, see Nadine Vivier, "Introduction", in Démelas and Vivier, Les propriétes collectives, pp. I 5-34.

36. See De Moor et al., The Management of Common Land. 
doubt methodological. A recent publication, Working Together: Collective Action, the Commons, and Multiple Methods in Practice, written by Amy Poteete, Marco A. Janssen, and Elinor Ostrom, is an excellent starting point for those among us who fear we might drown in the numerous different research methods tried out by commons researchers over the past thirty years. Such a fear is not entirely without justification; the authors show that many different methods have been applied in many different ways, from very explicit modelling in an experimental context to more descriptive work based on data collected from interviews.

Poteete, Janssen, and Ostrom's Working Together is in many ways a timely publication. For many years, commons have been approached from all kinds of different angles and all kinds of different methodologies have been applied - sometimes without the necessary consistency. Although the commons are currently a popular topic, whoever ventures into the woods of the methodologies applied so far to make sense of the subject is bound to get lost. It is certainly time for an understandable overview of all these methodologies, and a summary that shows the way forward. Although the authors remain kind sometimes too kind - in assessing various studies and their application of different methodologies, they also point out the advantages and disadvantages of each approach for the study of natural resource management, and suggest new ways of combining methodologies. And, after thoroughly discussing and illustrating the pros and cons of field methods, comparative field-based research, meta-analysis, collaborative field studies, models, laboratory experiments, and methods based on agent-based models, they also discuss various versions of empirical research with agent-based modelling.

Poteete et al. bring all the different methods together, and indicate clearly for which research questions one or another method is useful. They evaluate the contribution each method can make to our understanding of common-pool resources, with plenty of references to examples of research. One of their main conclusions is that, although many approaches have been tried, only very few studies have led to cross-country comparisons - the kind of comparisons needed for widely applicable models of how commoners and resources (natural resources or otherwise) interact, regardless of national or cultural background.

The only downside of the book - and this goes especially for the first few chapters - is that they keep insisting on the negative side-effects of interdisciplinary research, as an inherent aspect of commons studies. It is no doubt true that combining different disciplines and methodologies is difficult for any individual scientist. Yet a book devoted to methodological issues does not seem to be the right place to hammer on, time after time, about the unfavourable academic structure which commons researchers face, and comment on what (in their opinion) the career effects are.

It is evident that this book could not have been written without an extremely good knowledge of what goes on in the area of commons 
studies. All three authors have already attested to their expertise elsewhere, but the combination of Poteete, Janssen, and Ostrom leads to a very comprehensive and clear overview of the field. Little attention is, however, given to existing historical research. Historians usually do not follow very explicitly defined methodologies, but they should feel encouraged by this book to be more explicit about the methodological assumptions they do use implicitly. One of the things which the authors demonstrate quite successfully is that commons studies can benefit greatly from multi-method approaches, and also from long-term approaches in which the dynamics of commons are followed over long periods of time. The field-based research method which the authors describe corresponds quite closely with the type of retrospective archival research undertaken in historical commons research. Instead of including more methodological variety in historical commons research - a good strategy, but perhaps not a priority - it would be a better start if historians begin by identifying how they position their own research vis-à-vis the great diversity of commons studies across different disciplines.

Whether historians will feel constrained to do so probably depends also on whether they can link their own research questions to the central questions at issue in most commons research. In particular, social historians could play a useful role in linking what we know from sociological studies about the cooperative behaviour by individuals to issues of group dynamics, which are often of more concern in historical studies. For example, sociology has proved that group size, ${ }^{37}$ and heterogeneity, ${ }^{38}$ (to name just two factors that can differ from group to group) influence the level of cooperation within the group. Historians usually consider commoners as homogenous groups, but within groups of commoners, differences in social-economic background can also influence the perceived utility of the commons for each individual user - leading to differences in cooperative behaviour. ${ }^{39}$ Such differences are of central interest to social historians, but are still insufficiently investigated in commons-studies.

\section{CONCLUSION}

In this article, I have reviewed previous literature on the commons from various disciplines in a general way, and looked at three specific books recently published within three different disciplinary contexts: one by a

37. On this issue, see also: http://www.collective-action.info/_DEB_ICA_GEN_EffectGroup SizeLevel.

38. On this issue see also: http://www.collective-action.info/_DEB_ICA_GEN_Effect CommunityHomegeneityICAs.

39. T. De Moor, "Participation Is More Important than Winning: The Impact of Social-Economic Change on Commoners' Participation in I8th-19th-Century Flanders”, Continuity and Change, 25 (2010), pp. 405-433. 
historian, one by a group of historians and other researchers, and one by commons researchers interested in methodologies who have no background in history at all. My choice of these three books was fairly arbitrary, but their positive view of the potential of commons - whether explicitly stated (as in Poteete et al.), or implied (as in Kos) - resonates well with today's Zeitgeist.

While in the period from the late eighteenth century until the I970s people were pessimistic about the potential of governing resources collectively, we now see an opposite trend. But this new positive attitude does not originate from mainstream economists, and is not supported by national or international organizations. That is not surprising: the kind of institutions which the commons and current sharing initiatives stand for, are inspired by action "from below", and by ideas of self-governance. Do the new developments suffer from a romanticized perspective, or even an overtly self-fulfilling prophecy? An easy answer would be the usual boutade: "history will be the judge". In fact, history has already been the judge. Institutions for collective action, such as the commons and the guilds, managed to survive for extraordinarily long periods, mostly without significant government support. In many cases, their histories literally span half a millennium. Compared to that, few government organizations have managed to survive for even half a century.

The question for the coming decades is: can the commons offer a better more efficient, more effective, more equitable - solution for problems of resource use than that which the state and the market have to offer? That is a question at the core of many current initiatives across the Western world. ${ }^{4}$ To be continued .... . 